\title{
Linking the Self-Esteem to Organizational Citizenship Behavior
}

\author{
Dorothea Wahyu Ariani \\ Department of Management, Economics Faculty \\ Atma Jaya Yogyakarta University, Indonesia \\ J1 Babarsari No. 26 Yogyakarta, Indonesia
}

Tel: 62-274-487-711Ｅ-mail: dwariani@gmail.com

Received: April 4, 2012

Accepted: April 30, 2012

Online Published: June 5, 2012

doi:10.5430/bmr.v1n2p26

URL: http://dx.doi.org/10.5430/bmr.v1n2p26

\begin{abstract}
In this study I analyzed the relationships between organizational citizenship behavior (OCB), and self-esteem personality of banking industry in Indonesia. A survey is conducted by using questionnaires from the previous research. The samples consisted of 500 bank tellers as subordinates and 100 bank head tellers as immediate supervisors from the banking industry provided ratings of OCB. Validity and reliability tests are used to evaluate the questionnaire contents. I employed correlation and regression analyses to analyze the model. The results indicated that self-ratings and supervisor-ratings of OCB were not significantly correlated. Using Multi-Trait Multi-Method matrix, I find strong method effects, indicating that ratings from different sources provide different information. The results also indicated that there were significant differences in the mean ratings across the two sources. The result also indicates self-esteem affect five dimensions of self-ratings of OCB and four dimensions of supervisor-ratings of OCB. Self-esteem doesn't affect supervisor-ratings of civic virtue. Theoretical and practical implications are discussed.
\end{abstract}

Keywords: Organizational citizenship behavior, Self-rating, Supervisor-rating, Self-esteem personality

\section{Introduction}

Organizational Citizenship Behavior (OCB) is a unique aspect of individual activities in a work place; however, the activities are not formally required by their jobs, independent and not explicitly and formally stated in work procedures and remuneration system. Individual relation to the volunteer work is recognized as important for organization effectiveness and individual performance (Borman \& Motowidlo, 1997; Motowidlo \& Van Scotter, 1994; Motowidlo et al., 1997). Dennis W. Organ developed OCB which was explained by Bateman and Organ (1983) as well as Smith et al. (1983). OCB is not directly and explicitly in formal system and organizational reward. OCB is one of individual performance, it is named contextual performance. Organ (1997) suggested that those definitions did not provide much clarity; nothing that one's "job role" is dependent on the expectations and communication from the role sender.

OCB is carried out by individuals as a result of supervisors' responses and it influences the evaluation of individual, group, and organizational performance. Therefore, there is no agreement on who is the best evaluator on the behavior, oneself, colleagues, supervisor, in this case the immediate supervisor, or subordinates (Allen et al., 2000). Evaluation given by different parties gives different perspectives and it gives valuable information that improves the validity on individual performance evaluation (Van der Heijden \& Nijhof, 2004). Evaluators from different levels have different concepts on the role of each participant (Morrison, 1994; Lam et al., 1999; Cardona \& Espejo, 2002). Self-evaluation and what is given by other parties in Organizational Citizenship Behavior influences significantly in evaluating the motives of implementing the behavior (Rioux \& Penner, 2001; Finkelstein \& Penner, 2004; Penner et al., 2005). Supervisor's evaluation is used to eliminate problems related to subjectivity in self evaluating when judging a variable.

OCB has been often conceptualized as inherently a socially desirable class of behaviors. It has been the purpose of this paper to strip away any biases and attributions for social desirability and to examine the behavior in their strictly observable form. In most occupations, it is usually impossible to use objective measures of job performance (Nikolau \& Robertson, 2001). This has led researchers to adopt supervisor assessment of employee's performance. Supervisor-ratings have attracted most attention because they are easy to develop and simple to use. Supervisors' 
assessments are usually considered as the most important source of information for employees' behavior and performance at work in most work settings. However, supervisor-ratings have often been criticized for a wide variety of errors such as the similar-to-me effect, leniency, central tendency, and halo effect.

Motowidlo and Van Scooter (1994) have provided evidence that task and contextual performance both contribute independently to overall performance. Furthermore, their result shows that personality variables are more highly correlated with contextual performance than task performance. Individual behavior is influenced by two variables, i.e. the person him/herself and the situation which are known as dispositional and situational factors. Dispositional variables have been implicated as predictors of the highly related form of non task specific work performance that has been termed OCB. Konovsky and Organ (1996) said that the same personality traits that predict work attitudes may also predict OCB.

Link between personality and job performance was tenuous and inconsistent. Although Smith et al. (1983) initially suggested that OCB might be manifestation of a broader disposition toward prosocial behavior; much of the research on OCB and individual differences has failed to demonstrate a significant relationship (George, 1991; Konovsky \& Organ, 1996; Organ, 1994; Organ \& Lingl, 1995; Smith et al., 1983). Organ (1994) found that overall, the predicting OCB from measures of personality might take as disappointing, and that any idea of dispositional basis for OCB seems unsupportable. Hurtz and Donovan (2000) encourage future research aimed at theory based matching of personality constructs and dimensions of job performance, perhaps using composites of narrower facets.

The previous research indicated that core self-evaluation (CSE) personality relates to favorable individual and organizational outcomes including employee performance. CSE is a higher concept representing the fundamental evaluation that people make about themselves and their functioning in their environment (Judge, Van Vianen, \& De Peter, 2004). Individuals with positive CSE appraise themselves in a consistently positive manner across situation, such individual see themselves as capable, worthy, and in control of their lives. The CSE factor displayed higher correlation with motivation and performance (Erez \& Judge, 2001). CSE are fundamental evaluations that people hold about themselves and form the basis of other self-appraisals like neuroticism or emotional stability, self-esteem, generalized self-efficacy, and locus of control (Judge et al., 1998). Borman and Motowidlo (1997) found that personality variables are more strongly correlated with contextual performance than with task performance.

Studies of contextual performance have suggested that personality traits are likely to be particularly good predictors of contextual performance (Motowidlo \& Van Scooter, 1994). Personality plays a role in behaviors that are discretionary or performed in weak situations with limited external constructs. A weak situation does not provide clear incentive, support, or normative expectations of behavior. In strong situation, behavior is more a function of the situation than of personality. Hough and Schneider suggested that personality has greater relation with job performance in weak situations, as opposed to strong (Bono \& Judge, 2003). Personality reflects enduring tendencies to think, feel, and behave in certain ways that OCB are discretionary; there is a strong relationship between OCB and personality characteristics (Podsakoff et al., 2000).

In this study, we investigate links between individual personality attributes to perform citizenship behavior. The focus was on the trait of self-esteem in relation to individual contextual performance, based on prior predictions and empirical findings (Illes et al., 2006). Feelings of self-esteem predict lower employee turnover intentions, better service to clients, peers, and supervisor, and promote more time spent both on a job and in given career field. Self-esteem reflects the extent to which individuals believe they are capable, significant, and worthy. Self-esteem is individual differences that relatively stable. According to Korman's self consistency model of motivation, self-esteem is central to the explanation of employee motivation attitudes and behavior.

Using the guidelines state above, the purpose of this study is to investigate the relationship between self-esteem personality variables and OCB. We also need to know if it makes much difference in the result it. In this study, OCB is measured by other ratings and self-ratings. One could argue that much OCB might escape the notice of supervisors (the usual source of other ratings of $\mathrm{OCB}$ ) or even peers, and therefore be known only to the individual. Therefore, the purpose of this study is also to elucidate information on the disparity between self-ratings and supervisor-ratings of OCB in industrial banking in Indonesia.

\section{Literature Review}

Organ defined OCB as individual behavior that is discretionary, not directly or explicitly recognized by the formal reward system, and that in the aggregate promotes the effective functioning of the organization. By discretionary, we mean that the behavior is not an enforceable requirement of the role or the job description that is the clearly specifiable terms of the person's employment contract with the organization, the behavior is rather a matter of 
personal choice, such that its omission is not generally understood as punishable (Podsakoff et al., 2000). OCB describes actions in which employees are willing to go above and beyond their prescribed role requirements. Prior theory suggests and some researchers supports, the belief, that these behaviors are correlated with indicators of organizational effectiveness. This study adopts the repertoire of Organ's initial definition of OCB with five dimensions, altruism, courtesy, sportsmanship, civic virtue, and generalized compliance (Smith et al., 1983). Altruism is the helping of an individual coworker on task. Courtesy is alerting others in the organization about changes that may affect their work. Sportsmanship consists of behavior demonstrating tolerance of less than ideal conditions at work without complaining. Civic virtue consists of responsible participation in the affairs of the organization. Generalized compliance or conscientiousness is carrying at one's duties beyond the minimum requirements. OCB is carried out by individuals as a result of supervisors' responses and it influences the evaluation of individual, group, and organizational performance. Therefore, there is no agreement on who is the best evaluator on the behavior, oneself, colleagues, supervisor, in this case the immediate supervisor, or subordinates (Allen et al., 2000). One of the constraints in OCB research is the reliability and validity of the measurement systems employed especially the source of $\mathrm{OCB}$ rating.

Citizenship behavior is often subtle and difficult to measure (Schnake, 1991) due to its discretionary nature and the various beneficiaries of the behaviors (McNeely \& Meglino, 1994). For as long as 20 years of its development, there have been many issues and arguments on OCB, both as a concept and methodology. There are many things which can be considered as OCB within an organization, so there are many dimensions to be utilized. On top of the dimensional issue, another argument is on who is rating the behavior, oneself or others. According to Van der Heidjen dan Nijhof (2004), rating will be precise since individuals can exactly identify themselves and self-evaluation validity is higher than that of others. However, supervisor's evaluation is more reliable than self-evaluation. The focus is put on the resource of the evaluation theory. Since OCB consists of discretionary behaviors which are not formally required, the occurrence of citizenship behavior may not be recognized or be aware by others as compared to task performance.

The use of supervisor-ratings mitigates concerns regarding the problem of common method variance that can arise when self-ratings of OCB are obtained along with self-report of other variables of interest (Organ \& Ryan, 1995; Podsakoff \& Organ, 1986). Common method variance arises when measures of all variables investigated come from the same source. Schnake (1991) noted that supervisor ratings might be bias due to halo effect, memory distortion, and selective memory since OCB is so difficult to observe. Thornton compared self-ratings with other forms of rating and found that self-ratings tended to show more leniency error, less variability, and less discriminant validity, but had the advantage of being less susceptible to the halo effect (Lane \& Herriot, 1990). Based on the explanations on the different results on the research when using self-evaluation and supervisor evaluation, the basic question in this research is whether differences exist between self-evaluation and supervisor-evaluation in testing the relations of personality and the OCB?

Personality can potentially yield OCB in the workplace through several simultaneous and interrelated processes. Differences in personality may influence how individuals are motivated. Motivation may be in mechanism by which personality yields OCB. Personality is a dimension of human behavior that may both organize and direct behaviors. Barrick and Mount (1991) demonstrated that the personality-job performance relation was significantly stronger when perceptions of job autonomy were high (weak situation), in comparing to situations in which perception of autonomy were low. In a strong situation, the fact that certain behaviors are desired is conveyed by reinforcement of correct responses, normative expectations, and an environment that supports learning how to perform desired behaviors. A situation that lacks these characteristics is referred as "weak". The strength of a situation is based on the consistency of individuals' perceptions of appropriate behavior. Mischell extended his conceptualization of situations to suggest that strong situations constrain the expression of personality (Beaty et al., 2001). In strong situation, well recognized, and widely accepted guidelines for interaction, will reduce inter-individual variability. Most individuals in a strong situation construe the situation in the same way and tend to conform to expectation and norms.

Personality relates to internal factors such as dispositions and interpersonal strategies that explain individual behavior and the unique and relatively stable patterns of behaviors, thoughts, emotions shown by individuals. Personality constructs generally have little predictive power in a strong situation. In contrast, individual dispositions are more influential in a weak situation where individuals exhibit a wide range of appropriate attitudes and behaviors. Van Dyne et al. (2000) note that individual differences are the only antecedents of OCB on that they will be better predictors than other constructs such as satisfaction, commitments, and justice. 
The personality-contextual performance relation varies across perceptions of the types of performance behavior that are referred and rewarded. Issues relevant to the validity of personality dimensions for predicting job performance, such as faking and broad versus narrow personality dimensions are being investigated (Ashton, 1998; Ones \& Viswesvaran, 1996). In the last decade, personality trait that has received much attention in research relating dispositional constructs to employee behavior and attitudes is core self-evaluation (CSE). CSE refers to fundamental assessment that people make about their worthiness, competence, and capabilities (Bono \& Colbert, 2005) and is posited to be the underlying latent construct that accounts for shared variance among other self-evaluative measures (Judge et al., 2003). Judge et al. (2003) conclude that these four traits share a great deal of conceptual similarity because each represents a component of common core. CSEs are fundamental evaluations that people hold about themselves and form the basis of other self-appraisals like neuroticism or emotional stability, self-esteem, generalized self-efficacy, and locus of control (Judge et al., 1998). Judge et al. (1998) linked CSE to motivation, suggesting that CSE may influence decisions about whether to engage in behavior, how to effort to expend, and whether to persist in the face of setback or failure. With respect to multisource feedback, there are a number of factors on which CSE may have influence, including level of ratings, affective reactions to feedback, motivation to improve following negative or discrepant feedback.

This research focuses on self-esteem personality as antecedent of OCB. Wells and Marwell found that self-esteem reflects a person's overall evaluation of the self; it is multidimensional and composed of task and situation specific component (Pierce et al., 1989). Self-esteem is defined as a global evaluation of the self and it is typically measured by the degree to which the person endorses various evaluative statements about self (Judge et al., 1998). Self-esteem is the self perceived value that individuals have of themselves within a specific organizational context. It reflects people's sense of their own value within a particular setting and shows that extent to which their need for self-esteem is met by performing their role in the organization. Self-esteem doesn't involve feeling of superiority or of perfection, but self-esteem involves feelings of self-acceptance, self-respect, self-liking, self-competence, self-knowledge, and self-worth. Self-esteem is a prerequisite for productive behavior in general.

Self-enhancement theory posits that individual have a basic need to enhance their level of self-esteem. Individuals with high self-esteem will activate self-enhancing motivation to person better and might engage in OCB, whereas those low in self-esteem will activate self-protecting motivation to justify low performance. Both OCB and sense of self-esteem would be related to OCB using cognitive consistency theory which suggests that individuals are motivated to maintain attitudes and perform behaviors that consistent with their self-concept. Individuals higher in self-esteem would be more likely to engage in such behaviors that are congruent with positive self-esteem such as OCB (Avey et al., 2011).

According to self-consistency theory, people preserve their self views by thinking and behaving in ways that perpetuate their conception of self (Sharma \& Mavi, 2001). When all else is equal, people will enact and satisfied with those behavioral roles that maximize their sense of consistency. Low self-esteem individuals have negative self-concept and prefer negative feedback; high self-esteem individuals have positive self-concept and prefer positive feedback. According to self-enhancement theory, high self-esteem individuals, in comparison with low self-esteem individuals are more motivated and better able to enhance their self-worth. Individual with high self-esteem are motivated to do well on the job to maintain cognitive consistency with their high self-evaluations or that self-esteem provides a buffer against role stressors that would otherwise impede workplace motivation and performance. Therefore hypotheses can be concluded as below:

$\mathrm{H} 1$ There is difference in the means of self-ratings and supervisor ratings of each dimension of OCB

$\mathrm{H} 2$ : Self-esteem personality will be positively related to self-ratings of each dimension of OCB

H3: Self-esteem personality will be positively related to supervisor-ratings of each dimension of OCB

\section{Method}

Based on exploratory study by in-depth interviews with Bank Indonesia, the Central Bank as Indonesian banking supervisor, big cities, cities with high gross domestic regional product (Rp. 3,000,000.00 or more) have higher activity rates. General bank branches in the cities have far more clients than those in smaller towns with lower per capita. Therefore, the research focuses on 12 big cities in Java with high per capita that have many general bank branches. After deciding the research locations, based on the data taken from Data Department of the Information and Clearance of the Indonesian Central Bank in Jakarta, general bank branches are chosen. Letters asking for permission based on the central bank recommendation are sent to those branches. Getting the permission to carry out the research, bank staff are chosen (they are only taken out of permanent, full time cashiers) with more than one year 
experience. Permission is granted by 115 general banking branches from 12 big cities throughout Java. Zikmund et al. (2010) states that sampling size based on the researcher's consideration. In reality, all cashiers who meet the requirement can act as the research sampling. However, when the branch has more than five cashiers meeting the requirement, only five are taken. This method is used since a supervisor can only identify the behavior of at the most five subordinates (Van Dyne \& LePine, 1998; Cardona \& Espejo, 2002).

Questionnaire on the organizational citizenship behavior are taken from those developed by previous researchers, such as Konovsky and Organ (1996); Williams and Anderson (1991); Farh et al. (1990); Niehoff and Moorman (1993); Vey and Campbell (2004); Morrison, (1994); Takeuchi et al. (2004); Van Dyne et al. (1994). Individual personality variables that use personal self-esteem are taken from Judge et al. (2003). Questionnaire items are extracted based on the theories implemented in the study. Then, with varimax rotation and loading factor of minimum 0.4 as suggested by Hair et al. (2006). Table 1 shows reliabilities, means, and standard deviation of self-ratings and supervisor ratings of OCB.

\section{Results}

Hypothesis 1, which predicted that there are difference in the means of self-ratings and supervisor-ratings of OCB, was supported. Table 1 shows reliability, mean, and standard deviation of self-ratings and supervisor-ratings of each five OCB dimensions. The reliability of organizational citizenship behavior based on supervisor ratings $(\alpha=0.9002)$ which is higher than self rating $(\alpha=0.8519)$. These results are in accordance with the research of Van der Heijden and Nijhof (2004). This does not happen because the workers' self-rating is less valid, but more because the two raters have different self-image.

Table 1 show the average and relation between variables used in the research. The table shows that the average organizational citizenship behavior of self-ratings is (4.1521) higher than that of supervisor-ratings (4.0659) and the standard deviation of self-ratings of OCB is (0.0132) smaller than that of supervisor-ratings $(0.01645)$ which result in index rate of 314.55 for self-ratings and 274.17 for supervisor-ratings. It shows the existence of leniency bias in the OCB when using the self-ratings. There is a tendency to overvalue one as the average is higher. The smaller standard deviation also shows that the individuals tend to see themselves as good. On the other hand, supervisors' evaluation has a greater standard deviation and smaller average that show they are more objective in evaluating their subordinates' performance. With t-test of 4.525 , it shows that the evaluation of the two raters differ significantly. Further, supervisors' evaluation variance of 0.01645 is bigger than the self-evaluation of 0.0132 . It shows that the supervisors understand his or her subordinates' OCB as each cashier chief evaluates the OCB of five cashiers within his/her authority.

Insert Table 1 here

A t-test was conducted to test hypothesis 1, which postulated differences in the means of self-ratings and supervisor-ratings of OCB. The results indicate that for overall measure of OCB, there is a significant differences in the mean between self-ratings and supervisor-ratings of OCB $(t=4.525, \mathrm{p}=0.000$. Self-ratings (mean $=4.1521, \mathrm{SD}$ $=0.0132$ ) were significantly higher than supervisor-ratings (mean $=4.0659, \mathrm{SD}=0.01645)$. Significant differences were also found for each of the four dimensions of OCB, but not for civic virtue dimension. The results indicate that self-ratings were significantly higher than supervisor-ratings for four dimensions of OCB. The highest mean of self-ratings obtained is courtesy (mean $=4.6860, \mathrm{SD}=0.37418$ ) and the lowest mean obtained is civic virtue (mean $=3.5072, \mathrm{SD}=0.64811)$. The highest mean of supervisor-ratings were obtained is sportsmanship (mean $=0.4555$, $\mathrm{SD}=0.41257)$ and the lowest mean obtained is civic virtue (mean $=3.4484, \mathrm{SD}=0.64988$ ). The Cronbach alpha for supervisor-ratings of all OCB dimensions in higher than for self-ratings. The result indicates that reliability of supervisor-ratings $(\alpha=0.9002)$ is higher than self-ratings $(\alpha=0.8519)$. Reliability of supervisor-ratings of four OCB dimensions is higher than reliability of self-ratings of four OCB dimensions. Reliability of supervisor-ratings of civic virtue is lower than reliability of self-ratings of civic virtue. Hypothesis 1 is confirmed and the results indicate that self-ratings of OCB are significantly higher than supervisor-ratings of OCB. Table 2 shows correlations among all variables of this research and Table 3 shows linier regression analyses.

Insert Table 2 here

Insert Table 3 here

An examination of the correlation matrix indicates a strong correlation among the same source indices. Correlation between self-esteem personality and each of the five dimensions of self-ratings of OCB is significant. Hypothesis 2 suggests that self-esteem personality will be positively related to self-ratings of OCB. Examining the relationship between self-esteem personality and each of five dimensions of OCB based on self-ratings and supervisor-ratings is 
summarized in Table 3. Self-esteem personality affects each of five dimensions of OCB and overall OCB based on self-ratings. In other word, hypothesis 2 is supported.

Correlation between self-esteem personality and overall OCB based on supervisor ratings is significant. Hypothesis 3 suggests that self-esteem personality will be positively related to supervisor-ratings of OCB. Correlation between self-esteem personality and each of the four dimensions of supervisor-ratings of OCB is significant, but civic virtue dimension is not significant. Self-esteem personality affects overall OCB based on supervisor ratings and affects each of four dimensions of OCB based on supervisor-ratings. Civic virtue dimension is not affected significantly by self-esteem personality. Based on this result, hypothesis 3 was partially supported.

\section{Discussion}

The results of the research show that measuring the organizational citizenship behavior with the use of self-ratings and supervisor-ratings indicates a significant gap. The non-convergent evaluation of the two raters is supported by some theories. Wheery's theory of rating shows the existence of three factors that influence the performance evaluation, that is the evaluation on the ratee's actual job performance, some bias on raters' perception, memory on the ratee's performance, and miscalculation (Wheery \& Bartlett, 1982). Based on the theory, the gap between self-ratings and supervisor-ratings is caused by perception bias towards the OCB. Borman's (1997) research also shows the same results. He states that there are reasons for the gaps, amongst them are: (1) raters' different perspectives; (2) raters from different perspectives see the same work aspects but give different weight; and (3) raters from different perspectives observe samples of different behaviors.

Evaluating performance by using self-ratings has some weaknesses. Among others is true halo, a mistake or bias in evaluating each of the work dimensions (Scullen et al., 2000). Besides, the rater's bias and mistakes result from the influence of the interaction between raters and ratees, and also the existence of leniency bias, that is to tend to overvalue or undervalue. The correlation between self-ratings and supervisor-rating is considered low (see Harris \& Schaubroeck, 1988; Conway \& Huffcutt, 1997; Furnham \& Stringfield, 1994; Allen et al., 2000; Korsgaard et al., 2003; Van der Heidjen \& Nijhof, 2004). According to Harris and Schaubroeck (1988), the low correlation between the two raters is caused by egocentric bias, gaps between organizational levels, and opportunity to observe. Egocentric bias is a result of the high self assurance (Baird, 1977; Conway \& Huffcutt, 1997).

Numerous advantages of using multiple raters have been cited, for example enhanced ability to observe and measure various job facets, greater reliability, fairness and ratees' acceptance, and improved defensibility of the performance appraisal program from a legal standpoint (Harris \& Schaubroeck, 1988). Raters at different levels define and measure performance differently. Self-supervisor and peer-supervisor ratings exhibit for lower correlation than peer-self ratings. In terms of mean differences, on average, self-ratings were higher than supervisor-ratings. The basic explanation was reviewed as to why disagreement between raters may occur. The present findings are current with two versions of egocentric bias theory. Specifically, in accordance with attribution theory, observer displayed higher agreement than did actors with observer.

The next is that self-perception and self-improvement approaches also state that an individual with positive self-image will regard him/herself as a good performer. The balance and inappropriateness theories state that there is a factor that influences self-evaluation: workers' self image. In the balance theory, there is a need to keep stable and consistent orientation towards oneself, others and environment. All the three theories support the research findings. Individuals with high self-esteem should be more motivated to be good performers than those with low self-esteem. The mean of samples' self-esteem is high (mean $=4.0178$ ) and standard deviation of samples' self-esteem is 0.40605 . Based on previous research, people with high self-esteem expect to succeed more than do people with low self-esteem and will have emotional stamina to perform OCB. The more people perceives himself or herself to be competent, skilled, or qualified for a particular job, the higher will be his performance on his job.

The study shows that self-esteem personality significantly affects the overall OCB both by using the self-ratings and supervisor-ratings. This is consistent with Ralston's (1985) statement that the attitude to lick the boots of one's superior is mainly influence by individual factor than situational; and Ilies et al. (2006) opinion that attitudes do not just act as a bonding predictor in the OCB but a moderator in situational factors relation with the OCB; and Comeau and Griffith (2005) who states that on top of work setting, workers' behavior is also determined by personal characteristic, such as positive affect. It can be concluded that self-esteem personality affects the individual's organizational citizenship. Many studies have examined the relationship of personality traits to performance finding significant relationships between them (Barrick \& Mount, 1991). Organ argued that individual differences play an important role in predicting whether an employee would exhibit OCB (Organ, 1994). 
The result also shows that self-esteem personality doesn't affect civic virtue dimension based on supervisor-ratings. Civic virtue represents a macro-level interest in, or commitment to, the organization as a whole (Podsakoff et al., 2000). This is shown by willingness to participate actively in its organization, to monitor its environment for threats and opportunities, and to look out for its best interest. In banking industries in Indonesia, these activities are arranged clearly with reward and punishment. Therefore, civic virtue is a strong situation in banking industries in Indonesia.

In line with the self consistency theory, individuals who have high self-assurance will drive motivation to behave, both in improving organizational performance or for personal interests. The person also believes that he/she is able to carry out the general tasks given and has good internal control. Snyder said that good self confidence also allows a person to have stable emotional state (Penner et al., 1997). Self monitoring theory differentiates individuals with high self monitoring who are sensitive and responsive towards social and interpersonal signals on proper behavior in accordance with the expected roles from those with low self monitoring who are less responsive towards the signals (Warech \& Smither, 1998).

Besides, Hogan's socio-analytic theory also explains why certain behaviors that are favorable to society in personality measurement become task performance predictor (Hogan \& Holland, 2003). It is because the responses to the personality questionnaire items are not self reporting but self presentation. Personality variables powerfully influence when situational factor is weak and ambiguous (Beaty et al., 2001). This is in accordance with the research findings. The influence of the self-esteem personality variables towards the OCB is strong because there is a gap between supervisor and workers' perspectives in seeing the OCB. The self-esteem personality also drives workers' motivation and form behavior motives, the organizational and individual motives.

Robertson and Callinan (1990) concluded that personality needs to be given a more central role is explanation of behavior at work. Despite the important conceptual role for personality, the effect sizes appear to be relatively small. This is because the role of the situation and in particular the interaction between the situation and individual differences in personality. The interaction between job and organization variables and personality help to determine overall levels of performance, attachment, well being, or many of the other dependent variables mentioned earlier. The interaction of personality traits in predicting performance needs to be better understood.

Personality has more predictive power in a 'weak situation' (i.e. a situation which does not have strong demand characteristics or compelling external incentives). Personality constructs generally have little predictive power in a strong situation. Personality constructs are more influential in a weak situation where individuals exhibit wider range of appropriate attitudes and selection behavior (VanDyne et al., 2000). This research setting would be a weak situation because OCB has more community consequences in cooperative setting and more personal consequences in traditional organization. Korman suggested that individuals with high self-esteem are more likely to have positive attitude toward the organization, will be more likely to get involved and contribute to the organization

I should also bear in mind that prototype study of personality and OCB uses self-ratings to measure personality and supervisor-ratings to assess OCB. Mount et al. (1994) fund that subjects' personality ratings obtained from source other than self-ratings added significant incremental variance in performance criteria beyond that predicted self-ratings of personality. Ratings of OCB along with self-report of dispositional and attitudinal variables invite spuriously high correlations confound by common method variance. In fact, relationship between self-esteem personality and OCB with self-ratings is significant for five dimensions of OCB, Relationship between self-esteem personality and OCB with supervisor-ratings is significant for altruism, courtesy, sportsmanship, and generalized compliance. The self-esteem personality factor displayed higher correlation with performance. Individual with positive self-esteem factor tended to be better performers than those with negative self-esteem personality factor.

Mount et al. (1994) found that subjects' personality ratings obtained from sources other than self-ratings added significant incremental variance in performance criteria beyond that accounted for by self-ratings (Organ, 1994). Supervisor personality ratings of subject were better predictors of supervisor's performance rating than were self reports of personality. It appears that research on personality and OCB using self-ratings understate the extent to which personality and social reputation is related to OCB. Using self-ratings for personality might not relate to supervisor ratings for OCB.

\section{Conclusion}

The results of the study show that self-esteem personality is powerful variable that drive individuals' OCB. The self-esteem personality variable which has been claimed to influence OCB and which has not been proven as related to the $\mathrm{OCB}$, is actually a strong antecedent that drives a person to play a role which is not his/hers. The results also show that self-evaluation and supervisor evaluation towards the OCB differ significantly. 
The theoretical contribution of the research is the different strength of the three theories on driving the OCB antecedent. The methodological contribution is on the use of the two non-convergent of the two raters in studying the OCB. The supervisor-rating is better because it has bigger variance and deviation standard with smaller average than that of the self-rating. The independent and dependent variables evaluation uses the two ratings also result better than that done by using the self-rating only. The supervisor-rating reduces leniency bias and common method bias.

The research managerial contribution is the practical benefits from evaluating performance or unexpected behavior required by the role in evaluating workers' performance. Even though further study is still needed, the OCB gives positive influence that supports individual performance and organizational effectiveness. It shows that behavior which is not expected by the role is actually a standard requirement for workers to evaluate their performance.

\section{References}

Allen, T.D. ; Barnard, S.; Rush, M.C.; dan Russell, J.E.A. (2000). Ratings of Organizational Citizenship Behavior : Does The Source Make A Difference ? Human Resource Management Review, 10 (1): 97-114. [Online] Available: http://proquest.umi.com/pqdweb?did $=2412718121 \&$ sid $=4 \& F m t=2 \&$ clientId $=42792 \& R Q T=309 \&$ VName=PQD

Ashton, M.C. (1998). Personality and Job Performance: The Importance of Narrow Traits. Journal of Organizational Behavior, 19 (3): 289-303. [Online] Available: http://search.proquest.com/docview/224881753?accountid=44396

Avey, J.B.; Palanski, M.E.; Walumbwa, F.O. (2011). When Leadership Goes Unnoticed: The Moderating Role of Follower Self-Esteem on The Relationship between Ethical Leadership and Follower Behavior. Journal of Business Ethics, 98:573-582. http://dx.doi.org/10.1007/s10551-010-0610-2

Baird, L.S. (1977). Self and Supervisor Ratings of Performance : As Related to Self-esteem and Satisfaction with Supervision. Academy of Management Journal, 20 (2): 291-300. http://dx.doi.org/10.2307/255402

Barric, M.R. dan Mount, M.K. (1991). The Big Five Personality Dimensions and Job Performance: A Meta-Analysis. Personnel Psychology, $44 \quad$ (1): 1-26. [Online] Available: http://search.proquest.com/docview/220131864?accountid=44396

Bateman, T.S. dan Organ, D.W. (1983). Job Satisfaction and The Good Soldier : The Relationship Between Affect and Employees'Citizenship. Academy of Management Journal, 26 (4): 587- 595. http://dx.doi.org/10.2307/255908

Beaty, J.C. ; Cleveland. J.N. ; dan Murphy, K.V. (2001). The Relation Between Personality and Contextual Performance in "Strong" Versus "Weak" Situations. Human Performance, 14 (2):125-148. [Online] Available: http://content.ebscohost.com/pdf13_15/pdf/2001/7LX/01Apr01/4792798.pdf?T=P\&P=AN\&K=4792798\&S=R\&D=a ph\&EbscoContent=dGJyMMv17ESeprA4v\%2BbwOLCmr0qeqK9Ssqe4SK\%2BWxWXS\&ContentCustomer=dGJy MOzprkivq7ZPuePfgeyx44Dt6fIA

Bono, J.E. and Colbert, A.E. (2005). Understanding Responses To Multisource Feedback: The Role of Core Self-Evaluations. Personnel Psychology, $58 \quad$ (1): 171-203. [Online] Available: http://search.proquest.com/docview/220144259?accountid=44396

Borman, W.C. (1997). $360^{\circ}$ Ratings : An Analysis of Assuimptions and A Research Agenda For Evaluating Their Validity. Human Resource Management Review, 7 (3) : 290 - 315 . [Online] Available: http://proquest.umi.com/pqdweb?did=26866327\&sid $=5 \& F m t=2 \&$ clientId=42792\&RQT=309\&VName=PQD

Borman, W.C. dan Motowidlo, S.J. (1997). Task Performance and Contextual Performance: The Meaning For Personnel Selection Research. Human Performance, 10 (2): 99-109. [Online] Available: http://content.ebscohost.com/pdf10/pdf/1997/7LX/01Jun97/7309119.pdf?T=P\&P=AN\&K=7309119\&S=R\&D=aph \&EbscoContent=dGJyMMvl7ESeprA4v\%2BbwOLCmr0qeqK9Ssqm4SbaWxWXS\&ContentCustomer=dGJyMOzp rkivq7ZPuePfgeyx44Dt6fIA

Cardona, P. dan Espejo, A. (2002). The Effects of The Rating Source in Organizational Citizenship Behavior : A Multitrait-Multimethod Analysis. Barcelona : University of Navarra. Working Paper.

Comeau, D.J. dan Griffith, R.L. (2005). Structura1 Interdependence, Personality, and Organizational Citizenship Behavior. Personnel Review, 34 (3): 310-330. http://dx.doi.org/10.1108/00483480510591453

Conway, J.M. dan Huffcutt, A.I. (1997). Psychometric Properties of Multisource Performance Ratings: A Meta-Analysis of Subordinate, Supervisor, Peer, and Self-Ratings. Human Performance, 10 (4): 331-360. [Online] Available:

http://content.ebscohost.com/pdf10/pdf/1997/7LX/01Dec97/7309077.pdf?T=P\&P=AN\&K=7309077\&S=R\&D=aph 
\&EbscoContent=dGJyMMvl7ESeprA4v\%2BbwOLCmr0qeqK9Ssqu4Sq\%2BWxWXS\&ContentCustomer=dGJyM Ozprkivq7ZPuePfgeyx44Dt6fIA

Erez, A. and Judge, T.A. (2001). Relationship of Core Self-Evaluations to Goal Setting, Motivation, and Performance. Journal of Applied Psychology, 86 (6): 1270-1279. http://dx.doi.org/10.1037/0021-9010.86.6.1270

Farh, J.L. ; Podsakoff, P.M. ; dan Organ, D.W. (1990). Accounting for Organizational Citizenship Behavior : Leader Fairness and Task Scope versus Satisfaction. Journal of Management, 16 (4): 705-721. [Online] Available: http://proquest.umi.com/pqdweb?did=586778\&sid=19\&Fmt=2\&clientId=42792\&RQT=309\&VName=PQD

Finkelstein, M.A. dan Pennner, L.A. (2004). Predicting Organizational Citizenship Behavior: Integrating The Functional and Role Identity Approaches. Social Behavior and Personality, 32 (4): 383-398. [Online] Available: http://proquest.umi.com/pqdweb?did $=659681601 \&$ sid $=1 \& F m t=4 \&$ clientId=42792\&RQT=309\&VName=PQD

Furnham, A. dan Stringfield, P. (1994). Congruence of Self and Subordinate Ratings of Managerial Practices as a Correlate of Supervisor Evaluation. Journal of Occupational and Organizational Psychology, 67: 57-67. [Online] Available:

http://proquest.umi.com/pqdweb?did=880182\&sid=20\&Fmt=2\&clientId=42792\&RQT=309\&VName=PQD

George, J.M. (1991). State or Trait: Effects of Positive Mood on Prosocial Behaviors at Work. Journal of Applied Psychology, 76 (2): 299-307. http://dx.doi.org/10.1037/0021-9010.76.2.299

Hair, J.E.; Black, W.C.; Babin, B.J.; Anderson, R.E.; dan Tatham, R.L. (2006). Multivariate Data Analysis. $6^{\text {th }}$ edition. New Jersey : Prentice-Hall International Inc.

Harris, M.M. dan Schaubroeck, J. (1988). A Meta-Analysis of Self-Supervisor, Self-Peer, and Peer-Supervisor Ratings. Personnel Psychology, 41 (1): 43-62. [Online] Available: http://search.proquest.com/docview/220130452? accountid $=44396$

Hogan, J. dan Holland, B. (2003). Using Theory to Evaluate Personality and Job Performance Relations : A Socioanalytic Perspective. Journal of Applied Psychology, 88 (1): 100-112. http://dx.doi.org/10.1037/0021-9010.88.1.100

Hurtz, G.M. and Donovan, J.J. (2000). Personality and Job Performance: The Big Five Revisited. Journal of Applied Psychology, 85 (6): 869-879. http://dx.doi.org/10.1037/0021-9010.85.6.869

Iles, R.; Scott, B.A.; dan Judge, T.A. (2006). The Interactive Effects of Personal Traits and Experienced Sates on Individual Patterns of Citizenship Behavior. Academy Of Management Journal, 49 (3): 561-575. http://dx.doi.org/10.5465/AMJ.2006.21794672

Judge, T.A.; Erez, A.; and Bono, J.E. (1998). The Power of Being Positive: The Relationship between Positive Self-Concept and Job Performance. Human Performance, 11: 167-187. [Online] Available: http://content.ebscohost.com/pdf10/pdf/1998/7LX/01Jun98/7309092.pdf?T=P\&P=AN\&K=7309092\&S=R\&D=aph \&EbscoContent=dGJyMMvl7ESeprA4v\%2BbwOLCmr0qeqK9Ss6q4SLCWxWXS\&ContentCustomer=dGJyMOzp rkivq7ZPuePfgeyx44Dt6fIA

Judge, T.A. ; Erez, A. ; Bono, J.E. ; dan Thoresen, C.J (2003). The Core Self-Evaluation Scale: Development of A Measure. Personnel Psychology, $56 \quad$ (2): 303-331. [Online] Available: http://search.proquest.com/docview/220132845?accountid=44396

Judge, T.A.; Van Vianen, A.E.M.; and De Peter, I.E. (2004). Emotional Stability, Core Self-Evaluations, and Job Outcomes: A Review of The Evidence and an Agenda for Future Research. Human Performance, 17 (3): 325-346. [Online] Available: http://content.ebscohost.com/pdf13_15/pdf/2004/7LX/01Jul04/14183792.pdf?T=P\&P=AN\&K=14183792\&S=R\&D $=$ bth\&EbscoContent $=\mathrm{dGJyMNLr} 40$ SeprE4v\%2BbwOLCmr0qeqK9Ss6a4SbGWxWXS\&ContentCustomer=dGJyM PGtskm1qbNOuePfgeyx44Dt6fIA

Konovsky, M.A. dan Organ, D.W. (1996). Dispositional and Contextual Determinant of Organizational Citizenship Behavior. Journal of Organizational Behavior, 17 (3) : 253-266. [Online] Available: http://search.proquest.com/docview/224878975?accountid=44396

Korsgaard, M.A.; Meglino, B.M.; dan Lester, S.W. (2004). The Effect of Other Orientation on Self-Supervisor Rating Agreement. Journal of Organizational Behavior, 25: 873-891. [Online] Available: http://search.proquest.com/docview/224884034?accountid=44396 
Lam, S.S.K.; Hui, C. ; dan Law, K.S. (1999). Organizational Citizenship Behavior: Comparing Perspectives of Supervisors and Subordinates Across Four International Samples. Journal Of Applied Psychology, 84 (4): 594-601 http://dx.doi.org/10.1037/0021-9010.84.4.594

Lane, J. dan Herriot, P. (1990). Self-ratings, Supervisor Ratings, Positions, and Performance. Journal of Occupational Psychology, 63: 77-88. [Online] Available: http://search.proquest.com/docview/199361775?accountid=44396

McNeely, B.L.; dan Meglino, B.M. (1994). The Role of Dispositional and Situational Antecedents in Prosocial Organizational Behavior : An Examination of The Intended Beneficiaries of Prosocial Behavior. Journal of Applied Psychology, 79 (6) : 836-844. http://dx.doi.org/10.1037/0021-9010.79.6.836

Morrison, E.W. (1994). Role Definition and Organizational Citizenship Behavior : The Importance of The Employee Perspective. Academy of Management Journal, 37 (6) :1543-1567. http://dx.doi.org/10.2307/256798

Motowidlo, S.J.; Borman, W.C.; dan Schmit, M.J. (1997). A Theory of Individual Differences in Task and Contextual Performance. Human Performance, 10 (2): 71-83. [Online] Available: http://content.ebscohost.com/pdf10/pdf/1997/7LX/01Jun97/7309103.pdf?T=P\&P=AN\&K=7309103\&S=R\&D=aph \&EbscoContent=dGJyMMvl7ESeprA4v\%2BbwOLCmr0qeqK9Ss6y4SbSWxWXS\&ContentCustomer=dGJyMOzpr kivq7ZPuePfgeyx44Dt6fIA

Motowidlo, S.J. dan Van Scooter, J.R. (1994). Evidence That Task Performanxce Should be Distinguished From Contextual Performance. Journal of Applied Psychology, 79 (4): 475-480. http://dx.doi.org/10.1037/0021-9010.79.4.475

Mount, M.K.; Barrick, M.R.; and Strauss, J.P. (1994). Validity and Observer Ratings of The Big Five Personality Factors. Journal of Applied Psychology, 79 (2): 272-280.http://dx.doi.org/10.1037/0021-9010.79.2.272

Niehoff, B.P. dan Moorman, R.H. (1993). Justice as a Mediator of The Relationship Between Methods of Monitoring and Organizational Citizenship Behavior. Academy of Management Journal, 36 (3): 527-556. http://dx.doi.org/10.2307/256591

Nikolau, I and Robertson, I.I. (2001). The Five Factor Model of Personality and Work Behavior in Greece. European Journal of Work and Organizational Psychology, 10 (2): 161-186. http://dx.doi.org/10.1080/13594320143000618

Ones, D.S. and Viswesvaran, C. (1996). Bandwidth-Fidelity Dilemma in Personality Measurement For Personnel Selection. Journal of Organizational Behavior, 17: 609-626. [Online] Available: http://search.proquest.com/docview/224878767?accountid=44396

Organ, D.W. (1994). Personality and Organizational Citizenship Behavior. Journal of Management, 20 (2): 465-478. [Online] http://proquest.umi.com/pqdweb?did=52208\&sid=2\&Fmt=2\&clientId=42792\&RQT=309\&VName=PQD

Organ, D.W. dan Lingl, A. (1995). Personality, Satisfaction, and Organizational Citienship Behavior. The Journal of Social Psychology, $135 \quad$ (3) : 339-350. [Online] Available: http://content.ebscohost.com/pdf14_16/pdf/1995/JSY/01Jun95/9509274657.pdf?T=P\&P=AN\&K=9509274657\&S=

$\mathrm{R} \& \mathrm{D}=$ buh\&EbscoContent=dGJyMMvl7ESeprA4v\%2BbwOLCmr0qeqLFSrq24SbGWxWXS\&ContentCustomer=d GJyMOzprkivq7ZPuePfgeyx44Dt6fIA

Organ, D.W. dan Ryan, K. (1995). A Meta-Analytic Review of Attitudinal and Dispositional Predictors of Organizational Citizenship Behavior. Personnel Psychology, 48 (4) : 775-802. [Online] Available: http://search.proquest.com/docview/220130481? accountid=44396

Penner, L.A. ; Dovidio, J.F. ; Piliavin, J.A. ; dan Schroeder, D.A. (2005). Prosocial Behavior: Multilevel Perspectives. Annu. Rev. Psychol, 56: 365-392.

Penner, L.A. ; Midili, A.R. ; dan Kegelmeyer, J. (1997). Beyond Job Attitudes: A Personality and Social Psychology Perspective on The Causes of Organizational Citizenship Behavior. Human Performance, 10 (2): 111-131. [Online] Available:

http://content.ebscohost.com/pdf10/pdf/1997/7LX/01Jun97/7310022.pdf?T=P\&P=AN\&K=7310022\&S=R\&D=aph \&EbscoContent=dGJyMMv17ESeprA4v\%2BbwOLCmr0qeqK9Ss664S7eWxWXS\&ContentCustomer=dGJyMOzpr kivq7ZPuePfgeyx44Dt6fIA 
Pierce, J.L.; Gardner, D.G.; Cummings, L.L.; and Dunham, R.B. (1989). Organization-Based Self Esteem: Construct Definition, Measurement, and Validation. Academy of Management Journal, 32 (3): 622-648. http://dx.doi.org/10.2307/256437

Podsakoff, P.M. dan Organ, D.W. (1986). Self-reports ini Organizational Research. Journal of Management, 12 (4) : 531-544. [Online] Available: http://content.ebscohost.com/pdf9/pdf/1986/MGT/01Dec86/5687895.pdf?T=P\&P=AN\&K=5687895\&S=R\&D=buh \&EbscoContent=dGJyMMvl7ESeprA4v\%2BbwOLCmr0qeqLFSr6a4S7OWxWXS\&ContentCustomer=dGJyMOzpr kivq7ZPuePfgeyx44Dt6fIA

Podsakoff, P.M.; MacKenzie, S.B.; Paine, J.B.; dan Bachrach, D.G. (2000). Organizational Citizenship Behavior : Critical Review of The Theoretical and Empirical Literature and Suggestions for Future Research. Journal of Management, $26 \quad$ (3) $\quad 2 \quad 513 \quad-\quad 563 . \quad$ [Online] Available: http://proquest.umi.com/pqdweb?did=58179079\&sid=3\&Fmt=2\&clientId=42792\&RQT=309\&VName=PQD

Ralston, D.A. (1985). Employee Ingratiation : The Role of Management. Academy of Management Review, 10 (3): 477-487. http://dx.doi.org/10.5465/AMR.1985.4278963

Rioux, S.M. dan Penner, L.A. (2001). The Causes of Organizational Citizenship Behavior : A Motivational Analysis. Journal of Applied Psychology, 86, (6): 1306-1314 http://dx.doi.org/10.1037/0021-9010.86.6.1306

Robertson, I. dan Callinan, M. (1998). Personality and Work Behavior. European Journal of Work and Organizational Psychology, 7 (3): 321-340. http://dx.doi.org/0.1080/135943298398736

Schnake, M. (1991). Organizational Citizenship : A Review, Proposal, Model, and Research Agenda. Human Relations, 44: 735-759. [Online] Available: http://search.proquest.com/docview/231486194? accountid=44396

Scullen, S.E.; Mount, M.K.; dan Goff, M (2000). Understanding The Latent Structure of Job Performance Ratings. Journal of Applied Psychology, 85 (6): 956-970 http://dx.doi.org/10.1037/0021-9010.85.6.956

Sharma, V and Mavi, J. (2001). Self-Esteem and Performance on Word Tasks. The Journal of Social Psychology, 141 (6): 723-729. [Online] Available: http://search.proquest.com/docview/199797439? accountid $=44396$

Smith, C.A. ; Organ, D.W. ; dan Near, J.P. (1983). Organizational Citizenship Behavior : Its Nature and Antecedents. Journal of Applied Psychology, 68 (4): 653-663. [Online] Available: http://proquest.umi.com/pqdweb?did=1152664\&sid=14\&Fmt=2\&clientId=42792\&RQT=309\&VName=PQD

Takeuchi, R. ; Mrinova, S.V. ; Lepak, S.V. ; dan Moon, H.K. (2004). Justice Climate As A Missing Link for The Relationship Between High Investment HRM Systems and OCBS. Academy of Management Best Conference Paper.

Van der Heidjen, B.I.J.M. dan Nijhof, A.H.J. (2004). The Value of Subjectivity : Problems and Prospects for 360-degree Appraisal Systems. International Journal of Human Resource Management, 15 (3) May: 493-511. http://dx.doi.org/10.1080/0958519042000181223

Van Dyne, L. ; Graham, J.W. ; dan Dienesch, R.M. (1994). Organizational Citizenship Behavior: Construct Redefinition, Measurement, and Validation. Academy of Management Journal, 37 (4): 765-802. http://dx.doi.org/10.2307/256600

Van Dyne, L. ; Vandewalle, D. ; Kostova, T. ; Latham, M.E. ; dan Cummings, L.L. (2000). Collectivism, Propensity To Trust and Self-Esteem as Predictors of Organizational Citizenship in A Non-Work Setting. Journal of Organizational Behavior, $21 \quad$ : 3-23. [Online] Available: http://search.proquest.com/docview/224868135?accountid=44396

Van Dyne, L. dan LePine, J.A. (1998). Helping and Voice Extra-Role Behaviors: Evidence of Construct and Predictive Validity. Academy of Management Journal, 41 (1): 108-119. http://dx.doi.org/10.2307/256902

Vey, M.A. dan Campbell, J.P. (2004). In-Role or Extra-Role Organizatonal Citizenship Behavior : Which Are We Measuring ?. Human Performance, 17 (1): 119-135. [Online] Available: http://proquest.umi.com/pqdweb?did=628856801\&sid=16\&Fmt=2\&clientId=42792\&RQT=309\&VName=PQD

Warech, M.A. dan Smither, J.W. (1998). Self-Monitoring and 360-Degree Ratings. Leadership Quarterly, 9 (4): 449-474. [Online] Available: http://proquest.umi.com/pqdweb?did=38818970\&sid=17\&Fmt=2\&clientId=42792\&RQT=309\&VName=PQD Wherry, R.J. dan Bartlett, C.J. (1982). The Control Bias in Ratings : A Theory of Rating. Personnel Psychology, 35 (3) : 521-55. [Online] Available: http://search.proquest.com/docview/220136368?accountid=44396 
Williams, L.J. dan Anderson, S.E. (1991). Job Satisfaction and Organizational Commitment as Predictors of Organizational Citizenship and In-Role Behaviors. Journal of Management, 17 (3): 601-617. [Online] Available: http://proquest.umi.com/pqdweb?did=586812\&sid=18\&Fmt=2\&clientId=42792\&RQT=309\&VName=PQD

Zikmund, W.G.; Babin, B.J.; Carr, J.C.; dan Griffin, M. (2010). Business Research Methods, $8^{\text {th }}$ edition. Australia: South-Western Cengage Learning.

Table 1. Comparison of reliabilities means difference between self-ratings and supervisor ratings of OCB

\begin{tabular}{|l|c|c|c|c|c|c|c|c|}
\hline \multirow{2}{*}{$\begin{array}{c}\text { OCB } \\
\text { Dimension }\end{array}$} & \multicolumn{3}{|c|}{ Supervisor Ratings } & \multicolumn{3}{c|}{ Self-Ratings } & \multirow{2}{*}{ t } & \multirow{2}{*}{ Sig. } \\
\cline { 2 - 9 } & $\boldsymbol{\alpha}$ & Mean & SD & $\boldsymbol{\alpha}$ & Mean & SD & & \\
\hline Altruism & 0.8150 & 3.5193 & 0.65240 & 0.7480 & 3.6085 & 0.56636 & 2.866 & $0.004^{*}$ \\
\hline Courtesy & 0.8161 & 4.4533 & 0.54851 & 0,7433 & 4.6860 & 0.37418 & 9.530 & $0.000^{*}$ \\
\hline Sportsmanship & 0.7355 & 4.4555 & 0.41257 & 0.7147 & 4.4067 & 0.41087 & -6.575 & $0.000^{*}$ \\
\hline Civic Virtue & 0.6881 & 3.4484 & 0.64988 & 0.6986 & 3.5072 & 0.64811 & 1.740 & 0.082 \\
\hline $\begin{array}{l}\text { Generalized } \\
\text { Compliance }\end{array}$ & 0.8096 & 4.4528 & 0.54985 & 0.6490 & 4.5522 & 0.44923 & 3.942 & $0.000^{*}$ \\
\hline Overall OCB & 0.9002 & 4.0659 & 0.01645 & 0.8519 & 4.1521 & 0.0132 & 4.525 & $0.000^{*}$ \\
\hline
\end{tabular}

$\mathrm{N}=500 * \mathrm{p}<0.05$

Table 2. Correlation between self-ratings, supervisor rating, and Self-esteem

\begin{tabular}{|c|c|c|c|c|c|c|c|c|c|c|c|c|c|c|}
\hline & & 1 & 2 & 3 & 4 & 5 & 6 & 7 & 8 & 9 & 10 & 11 & 12 & 13 \\
\hline 1 & OCB & 1 & & & & & & & & & & & & \\
\hline 2 & Alt $-S$ & $0.709 *$ & 1 & & & & & & & & & & & \\
\hline 3 & Cour-S & $0.623 *$ & $0.260^{*}$ & 1 & & & & & & & & & & \\
\hline 4 & Sport-S & $0.643 *$ & $0.237^{*}$ & $0.429 *$ & 1 & & & & & & & & & \\
\hline 5 & Civic-S & $0.750 *$ & $0.647^{*}$ & $0.253^{*}$ & $0.316^{*}$ & 1 & & & & & & & & \\
\hline 6 & Gen-S & $0.645^{*}$ & $0.273^{*}$ & $0.405^{*}$ & $0.373^{*}$ & $0.266^{*}$ & 1 & & & & & & & \\
\hline 7 & ОСВНТ & $0.191 *$ & $0.139 *$ & $0.181 *$ & $0.120 *$ & $0.093 *$ & $0.142 *$ & 1 & & & & & & \\
\hline 8 & Alt-U & $0.162 *$ & 0.173 & $0.145^{*}$ & 0.045 & 0.045 & $0.109 *$ & $0.801^{*}$ & 1 & & & & & \\
\hline 9 & Cour-U & $0.091 *$ & $0.096^{*}$ & $0.151^{*}$ & 0.011 & 0.011 & 0.053 & $0.709 *$ & $0.427 *$ & 1 & & & & \\
\hline 10 & Sport-U & $0.143 *$ & 0.043 & $0.118^{*}$ & $0.146^{*}$ & $0.092 *$ & $0.112 *$ & $0.665^{*}$ & $0.375^{*}$ & $0.463 *$ & 1 & & & \\
\hline 11 & Civic-U & $0.128 *$ & 0.070 & $0.079 *$ & $0.079 *$ & $0.138 *$ & 0.052 & $0.737 *$ & $0.584 *$ & $0.311 *$ & $0.313^{*}$ & 1 & & \\
\hline 12 & Gen-U & $0.169 *$ & $0.094 *$ & $0.147^{*}$ & $0.100 *$ & 0.050 & $0.203 *$ & $0.708^{*}$ & $0.396^{*}$ & $0.446^{*}$ & $0.507 *$ & $0.316^{*}$ & 1 & \\
\hline 13 & Self-est. & $0.450^{*}$ & $0.367^{*}$ & $0.267^{*}$ & $0.268^{*}$ & $0.311 *$ & $0.297 *$ & $0.122 *$ & $0.083 *$ & $0.103 *$ & $0.147^{*}$ & 0.049 & $0.088^{*}$ & 1 \\
\hline
\end{tabular}

$\mathrm{N}=636 * \mathrm{p} \leq 0,01 \mathrm{~S}=$ self-rating $\mathrm{U}=$ supervisor ratings 
Table 3. Linear regression analysis

\begin{tabular}{|l|l|l|r|r|r|}
\hline Equation & $\begin{array}{l}\text { Dependent } \\
\text { Variable }\end{array}$ & $\begin{array}{l}\text { Independent } \\
\text { Variable }\end{array}$ & \multicolumn{1}{l|}{ B } & \multicolumn{2}{l|}{ R2 } \\
\hline \multicolumn{5}{|l|}{ Self-Ratings. } \\
\hline 1 & Altruism & Self-esteem & 0.367 & 0.133 & 0.000 \\
\hline 2 & Courtesy & Self-esteem & 0.267 & 0.070 & 0.000 \\
\hline 3 & Sportsmanship & Self-esteem & 0.268 & 0.070 & 0.000 \\
\hline 4 & Civic Virtue & Self-esteem & 0.311 & 0.095 & 0.000 \\
\hline 5 & Generalized & Self-esteem & 0.297 & 0.087 & 0.000 \\
\hline 6 & OCB & Self-esteem & 0.450 & 0.201 & 0.000 \\
\hline Supervisor Ratings & & & & 0.035 \\
\hline 1 & Altruism & Self-esteem & 0.083 & 0.005 & 0.035 \\
\hline 2 & Courtesy & Self-esteem & 0.103 & 0.009 & 0.010 \\
\hline 3 & Sportsmanship & Self-esteem & 0.147 & 0.020 & 0.000 \\
\hline 4 & Civic Virtue & Self-esteem & 0.049 & 0.001 & 0.213 \\
\hline 5 & Generalized & Self-esteem & 0.088 & 0.006 & 0.027 \\
\hline 6 & OCBHT & Self-esteem & 0.122 & 0.013 & 0.002 \\
\hline
\end{tabular}

